\title{
Isolation of Cellular Clones of Murine Melanoma Resistants to the Photodynamic Therapy and Characterization of Some Mechanisms Involved in the Radioresistance
}

\author{
Ramón-Gallegos E. ${ }^{1}$, Rosas-Flores L. ${ }^{1}$, \\ Barrera-Mendoza C.C. ${ }^{1}$, Herrera-Carrillo Z. ${ }^{1}$, \\ González-Agüero G. ${ }^{1}$, Estrada-Manrique G. ${ }^{1}$ and Cruz-Orea A. ${ }^{2}$ \\ ${ }^{1}$ Lab. de Citopatología Ambiental, \\ Escuela Nacional de Ciencias Biológicas, \\ Instituto Politécnico Nacional, Campus Zacatenco, \\ Unidad Profesional "Adolfo López Mateos" Calle Wilfrido Massieu esquina Cda. \\ Manuel Stampa Zacatenco, Del. Gustavo A. Madero, C.P. 07738, \\ ${ }^{2}$ Departamento de Física, Centro de Investigación y Estudios Avanzados-IPN, \\ México
}

\section{Introduction}

In the world, the skin cancer is by far the most common of all cancers. Melanoma accounts for less than 5\% of skin cancer cases but causes 75\% of skin cancer deaths (ACS, 2011). 132,000 melanoma skin cancers occur globally each year (WHO, 2011). In Mexico there is an evident increase of this neoplasia, with a growth of almost $500 \%$ in the last few years (Hernandez, 2005). The malignant melanoma is the most lethal of all skin cancers, due to its great capacity to produce metastasis and its chemotherapy-resistant properties that stand as challenging barriers to successful treatment (Kim, et al., 2010). For melanoma there is not an effective treatment, in the $95 \%$ of cases surgery is the choice therapy. Other alternatives included chemotherapy, immunotherapy, radiotherapy and a combination of these. Another strategy being explored is photodynamic therapy (PDT), a non-invasive selective therapy that opens new perspectives on the treatment of cancer. PDT emerges like a hopeful treatment for cancer and other diseases (Paras, 2003), is a low invasive treatment based on photosensitizer drugs that are administrated to the patients and can be retained on a selective mode for the ill tissue more than the normal tissue (Mang, 2004). This therapeutic procedure has been applied in the treatment of many hyper proliferative diseases of keratinocytes (Bugaj et al., 2004).

The action of photodynamic therapy is based on the use of visible light or near infrared, a photosensitizer and the presence of molecular oxygen $\left(\mathrm{O}_{2}\right)$ on transformed cells (like tumor cells); light is absorbed for the photosensitizer and this action is used to activate the oxygen (Bonnett, 2000) present into cancerous cells and to generate reactive oxygen species (mainly 
singlet oxygen), that are potentially cytotoxic causing lethal damage to the cell and/or inhibits angiogenesis (Bugaj et al., 2004). Various photosensitizing drugs have been developed, such as 5-aminolevulinic acid (ALA) that unlike other PDT drugs is not a photosensitizer. When taken up by cancerous cells it is converted by a naturally occurring biosynthetic process into the photosensitizer protoporphyrin IX (PpIX). It is known that PpIX is present at low concentrations in normal cells and high concentration in tumor cells, the enzyme ferrochelatase, which converts protopophyrin IX to heme, has been found to be reduced, whereas the opposite situation has been found for porphobilinogen deaminase (Van-Hillegerberg et al., 1994). ALA can be applied topically, and was approved by the FDA in 1999 for the treatment of actinic keratosis (Zhu \& Finlay, 2008). In dermatology the use of ALA has had good results on superficial tumors, however, this treatment is not recommended for pigmented tumors, like melanoma (Juzenas et al., 2002). There are many hypotheses where this problem has been discussed; maybe the presence of melanin on tumoral cells absorbs the light use on PDT on the tumor (Sheleg et al., 2004) in addition it has been considered an interaction between melanin and porphyrins, this can reduce the absorbance and generate non fluorescent compounds. However, there is little information available about PDT efficiency using ALA and derivates on the treatment of melanoma (Juzenas et al., 2002).

The aim of the present study was to obtain resistant clones of murine melanome by several photodynamic treatments and to study some factors that could be involved in the PDTresistant such as: biosynthesis capacity of PpIX stimulated by ALA, concentration melanin and mitochondrial activity.

\section{Material and methods}

\subsection{Cell lines and culture conditions}

Murine melanoma cells B16F0 (metastatic melanoma, number CRL-6322, ATCC) and B16F10 (number CRL-6475, ATCC) both isolated from the primary tumor C57BL/6J were cultured in DMEM-F12 medium supplemented with $10 \%$ fetal bovine serum (FBS) and $100 \mathrm{U} / \mathrm{mL}$ of penicillin and $100 \mathrm{U} / \mathrm{mL}$ of streptomycin. Cells were cultured at $37^{\circ} \mathrm{C}$ in $5 \% \mathrm{CO}_{2}$.

\subsection{Determination of intra and extra-cellular PpIX induced by ALA}

Cells were plated into 6-well plates at a cell density of $8 \times 10^{5}$ per well in $2 \mathrm{~mL}$ of DMEM supplemented with $10 \%$ FBS. After $24 \mathrm{~h}$ the medium was removed and cells were exposed to $0,25,50,75,100$ and $150 \mu \mathrm{g}$ of ALA/mL of serum-free medium for $4 \mathrm{~h}$ in darkness at $37^{\circ} \mathrm{C}$. Afterward, the medium was removed and collected in centrifuge tubes that contained $200 \mu \mathrm{L}$ of celita in 5\% saline to its subsequent analysis. The cells were washed with saline phosphate buffer (PBS, pH 7.4) and detached with $500 \mu \mathrm{L}$ trypsin/EDTA. Following cells were spun at 200xg, supernatant was removed and cells were rinsed once in PBS, then collected by centrifugation and lysed in $0.2 \mathrm{~mL}$ of $5 \%$ celite. To quantify the intra and extra-cellular PpIX it was used the Piomelli spectrofluorometry assay for free erythrocyte porphyrins (Piomelli, 1973) as adapted for cultured cells was used to quantify PpIX (Ramón et al., 1999). PpIX levels were read directly as $\mu \mathrm{g} /$ cells using a Perkin Elmer LS-2B spectrofluorometer calibrated with coproporphyrin I ( $0.05 \mu \mathrm{g} / \mathrm{mL}$; Sigma) stock solution (excitation wavelength $408 \mathrm{~nm}$, emission $608 \mathrm{~nm}$ ). All assays were performed in triplicate. A blank was prepared in parallel by replacing the cellular suspension with $40 \mu \mathrm{L}$ of saline solution. 


\subsection{Photodynamic treatment}

30,000 cells/well were seeded in 96 well plates and these were exposed to $0,25,50,75,100$, $125,150 \mu \mathrm{g}$ of ALA/mL of culture medium serum free for $4 \mathrm{~h}$. This proceeding was applied to the parental lines, B16F0 and B16F10, and irradiated with an argon laser with $70 \mathrm{~mW}$ of power and with a light dose of $64.3 \mathrm{~J} / \mathrm{cm}^{2}$. The used groups were: negative control (cells without ALA and irradiation), irradiation control (irradiated cells only), and treated cells group (cells with ALA and irradiation). In all the experiments the B16F0 and B16F10 cells were conserved in darkness before and after irradiation.

\subsection{Cell survival rate by red neutral-red assay}

After exposing cells to the different conditions mentioned above cell viability was measured by neutral-red spectrophotometric assay (Borenfreud and Shopis, 1985). The medium containing ALA was removed from the wells and replaced with $100 \mu \mathrm{L}$ of fresh medium per well containing $100 \mu \mathrm{L}$ of neutral red. The plates were then returned to the incubator for $3 \mathrm{~h}$. Medium was subsequently removed, and the cultures were washed rapidly with a mixture of $40 \%$ formaldehyde and $10 \% \mathrm{CaCl}_{2} \mathrm{VN}(4: 1)$. A mixture of $1 \% \mathrm{VN}$ acetic acid and $50 \%$ $\mathrm{V} / \mathrm{V}$ ethanol (1:1) was then added to extract the neutral red. The plate was shaken for $60 \mathrm{~s}$ and left to stand at room temperature for $15 \mathrm{~min}$. The absorbance of the solubilized dye was subsequently read at $540 \mathrm{~nm}$. Quantification of the extracted dye was correlated with the live cell number. Control wells were prepared in parallel, and these cells were exposed to neutral red, but not to ALA. The percentage of viable cells in the cell population at each concentration of the test agent was calculated by means of the equation 1 .

$$
\% \text { viability }=\frac{\text { Mean absorbance of treated cells }}{\text { Mean absorbance of control cells }} \times 100
$$

\subsection{Obtainment PDT-resistant clones (PDTR)}

B16F0 and B16F10 cells were seeded into each well of a 96-well plate before treatment. Cells were incubated for $24 \mathrm{~h}$ following administration of ALA at a concentration of 125 and 150 $\mu \mathrm{g} / \mathrm{mL}$ respectively, in serum-free medium. After, they were exposed to PDT with a light dose of $64.3 \mathrm{~J} / \mathrm{cm}^{2}$ in one exposition. $24 \mathrm{~h}$ after irradiation, cells were harvested with EDTAtrypsin and centrifuged for $2 \mathrm{~min}$ at $224 \times \mathrm{xg}$. The supernatant was discarded and cells were resuspended in $1.0 \mathrm{~mL}$ of medium supplemented with FBS and plated in a culture bottle. In parallel one experiment was realized with the same conditions utilizing a light dose of 64.3 $\mathrm{J} / \mathrm{cm}^{2}$. In both cases the viability was measured with neutral red method.

\subsection{Melanin determination}

This quantification was performed for all cell lines. Cells were exposed to their respectively ALA concentration and incubated for $4 \mathrm{~h}$. Medium was recovered for measure extracellular melanin and cells were washed with PBS and detached with trypsin-EDTA, this solution was quenched after 15-20 min with $1 \mathrm{~mL}$ of DMEM supplemented with $10 \%$ FBS. Cells were centrifuged at $224 \times \mathrm{xg}$ and washed with $1 \mathrm{~mL}$ PBS, resuspended in $1 \mathrm{~mL} \mathrm{NaOH} 1 \mathrm{M}$ in DMSO $10 \%$ and incubated at $80^{\circ} \mathrm{C}$ for $2 \mathrm{~h}$. It was centrifuged at $224 \times \mathrm{xg}$ and supernatant was recovered to measure intracellular melanin. A blank of $1 \mathrm{M} \mathrm{NaOH}$ in DMSO $10 \%$ was prepared in parallel. Absorbance was measured at $420 \mathrm{~nm}$, the amount of melanin was expressed in 
absorbance units (a.u.) per cell number, according to the methodology described by Rad (Rad, et al., 2004).

\subsection{Assessment of mitochondrial activity by MTT assay}

The mitochondrial activity was determined by the 3-(4,5-dimethylthiazol-2-yl)-2,5diphenyltetrazolium bromide (MTT) assay (Mossman, 1983). The cell lines B16F0, B16F10 and cellular clones PDT-resistant were exposed to 0, 25, 50, 75, 100, 125, $150 \mu \mathrm{g}$ of $\mathrm{ALA} / \mathrm{mL}$ for $4 \mathrm{~h}$. Then, the medium containing ALA was removed from the wells and replaced with $100 \mu \mathrm{L}$ of MTT reagent diluted in DMEM medium serum-free $(25 \mu \mathrm{g} / \mathrm{mL})$ at $37^{\circ} \mathrm{C}$. After $4 \mathrm{~h}$, the obtained formazan products were reconstituted in $0.04 \mathrm{~N} \mathrm{HCl}$ in isopropyl alcohol. The reduction of MTT by the viable cells was measured by an absorbance maximum at $540 \mathrm{~nm}$.

\subsection{Determination of mitochondrial abundance by MitoTracker Green FM ${ }^{\circledR}$}

In order to evaluate the mitochondrial abundance were used the MitoTracker Green FM ${ }^{\circledR}$ selective probes (Invitrogen). It was used according to manufacturer's conditions. Fluorescence was observed in a Nikon EFD-3.

\subsection{Statistical analysis}

Two-way analysis of variance (ANOVA) was performed for all the assessments made. In the case of the determination of mitochondrial abundance the Mann-Whitney rank-sum test was performed. The level of significance was set at $\mathrm{P}<0.05$. The tests were performed with SigmaStat version 3.1 for Windows (Jandel Scientific).

\section{Results}

\subsection{Obtainment of PDT-resistant clones (PDTR)}

Before of obtaining PDT-resistant melanoma clones from parental melanoma cells it was necessary to know the ALA concentration that induces the maximum intracellular accumulation of PpIX and afterwards to find this information in the PDT-resistant melanoma clones.

\subsection{Intra and extracellular PpIX accumulation induced by ALA for 24 hours in B16F0 and B16F10 with their clones PDT-resistant}

It was found that all ALA concentrations tested $(25,50,75,100,125$ and $150 \mu \mathrm{g}$ of $\mathrm{ALA} / \mathrm{mL}$ ) induced significatively the intracellular accumulation of PpIX in comparison to the basal level (0 mg of ALA/mL) (Table 1). B16F10 accumulates 43.0 times more PpIX than basal level of B16F0, in basal conditions, did not accumulate PpIX but its concentration reached up to $2 \mu \mathrm{g}$ of PpIX $/ 8 \times 10^{5}$ cells and when it is compared with their intracellular PpIX concentration $\left(1.64 \mu \mathrm{g} / 8 \times 10^{5}\right.$ cells) at lest ALA concentration is possible to found that B16F0 accumulates 1.4 times. From this results it was selected the ALA concentration for PDT application; for the B16F0 was $125 \mu \mathrm{g} / \mathrm{mL}$ and for B16F10 was 150 $\mu \mathrm{g} / \mathrm{mL}$. The low level of extracellular PpIX (Table 1) shows that the majority of PpIX is keept into the cells, this is important because the PpIX acts intracellularly as a response to PDT. The B16F0 cells accumulate from 2 to 9 times more PpIX than B16F10 at $\leq 125 \mu \mathrm{g} / \mathrm{mL}$ of ALA (Figure 1A). 
After obtaining cellular PDT-resistant clones the parental cells were irradiated at $64.3 \mathrm{~J} / \mathrm{cm}^{2}$ with a concentration of ALA of $125 \mu \mathrm{g} / \mathrm{mL}$ for B16F0 and $150 \mu \mathrm{g} / \mathrm{mL}$ for B16F10. Resistant cells are the ones that survive to this irradiation conditions. To determinate if PpIX accumulation were accumulated in PDT-resistant clones a similar experiment was performed (Table 2). B16F0-PDTR cells in basal condition accumulated PpIX (Tables 1 and 2) and when these cells were exposed to ALA at minimal concentration tested $(25 \mu \mathrm{g} / \mathrm{mL})$ accumulated 11 times more PpIX in comparison to basal level and 30 times at $125 \mu \mathrm{g} / \mathrm{mL}$ of ALA. B16F10-PDTR has a similar response; in basal conditions has 3 times more PpIX than B16F10, but when this is compared with ALA at 125 and $150 \mu \mathrm{g} / \mathrm{mL}$ intracellular PpIX concentration increases 44 and 16 times more, in comparison with the basal level. Therefore, in the PDT-resistant clones obtained (B16F0-PDTR and B16F10-PDTR) it can be seen that these when exposed to ALA accumulated the highest concentration of PpIX in comparison to parental melanoma cells, in the other hand using low ALA concentration is possible to obtain high levels of intracellular PpIX. The B16F0-PDTR cells accumulated from 2 to 8 times more PpIX than B16F10-PDTR at $\leq 150 \mu \mathrm{g} / \mathrm{mL}$ of ALA (Figure 1B).

\begin{tabular}{|c|c|c|c|c|}
\hline \multirow{2}{*}{$\begin{array}{c}\text { ALA } \\
(\mu \mathrm{g} / \mathrm{mL})\end{array}$} & $\begin{array}{c}|c| \\
\text { Intracellular } \\
\left(\mu \mathrm{g} / 8 \times 10^{5}\right. \\
\text { cells })\end{array}$ & $\begin{array}{c}\text { Extracellular } \\
(\mu \mathrm{g} / \mathrm{mL} \text { of } \\
\text { culture medium })\end{array}$ & $\begin{array}{c}\text { Intracellular } \\
\left(\mu \mathrm{g} / 8 \times 10^{5} \text { cells }\right)\end{array}$ & $\begin{array}{c}\text { Extracellular } \\
(\mu \mathrm{g} / \mathrm{mL} \text { of } \\
\text { culture medium })\end{array}$ \\
\hline 0 & $0.00 \pm 0.001$ & $0.011 \pm 0.001$ & $0.06 \pm 0.02$ & $0.011 \pm 0.000$ \\
\hline 25 & $1.64 \pm 0.11$ & $0.038 \pm 0.001$ & $0.18 \pm 0.02$ & $0.041 \pm 0.004$ \\
\hline 50 & $1.89 \pm 0.10$ & $0.051 \pm 0.001$ & $0.35 \pm 0.02$ & $0.037 \pm 0.001$ \\
\hline 75 & $2.24 \pm 0.07$ & $0.058 \pm 0.004$ & $0.53 \pm 0.00$ & $0.045 \pm 0.001$ \\
\hline 100 & $2.04 \pm 0.06$ & $0.058 \pm 0.003$ & $0.99 \pm 0.07$ & $0.057 \pm 0.003$ \\
\hline 125 & $2.21 \pm 0.04$ & $0.062 \pm 0.001$ & $1.46 \pm 0.13$ & $0.057 \pm 0.002$ \\
\hline 150 & $2.00 \pm 0.19$ & $0.071 \pm 0.000$ & $2.45 \pm 0.02$ & $0.062 \pm 0.004$ \\
\hline
\end{tabular}

Table 1. Intra and extracellular PpIX in B16F0 and B16F10 cells exposed to different ALA concentration for $24 \mathrm{~h}$

\begin{tabular}{|c|c|c|c|c|}
\hline \multirow{2}{*}{$\begin{array}{c}\mathrm{ALA} \\
(\mu \mathrm{g} / \mathrm{mL})\end{array}$} & $\begin{array}{c}\text { Intracellular } \\
\left(\mu \mathrm{g} / 8 \times 10^{5} \mathrm{cells}\right)\end{array}$ & $\begin{array}{c}\text { Extracellular } \\
(\mu \mathrm{g} / \mathrm{mL} \text { of } \\
\text { culture } \\
\text { medium })\end{array}$ & $\begin{array}{c}\text { Intracellular } \\
\left(\mu \mathrm{g} / 8 \times 10^{5} \mathrm{cells}\right)\end{array}$ & $\begin{array}{c}\text { Extracellular } \\
(\mu \mathrm{g} / \mathrm{mL} \text { of } \\
\text { culture } \\
\text { medium })\end{array}$ \\
\hline 0 & $0.20 \pm 0.00$ & $0.017 \pm 0.001$ & $0.19 \pm 0.00$ & $0.022 \pm 0.00$ \\
\hline 25 & $2.21 \pm 0.02$ & $0.046 \pm 0.002$ & $0.28 \pm 0.00$ & $0.051 \pm 0.004$ \\
\hline 50 & $4.42 \pm 0.17$ & $0.054 \pm 0.004$ & $2.41 \pm 0.1$ & $0.073 \pm 0.002$ \\
\hline 75 & $5.46 \pm 0.35$ & $0.054 \pm 0.000$ & $4.88 \pm 0.19$ & $0.074 \pm 0.004$ \\
\hline 100 & $5.44 \pm 0.47$ & $0.059 \pm 0.002$ & $5.51 \pm 0.47$ & $0.086 \pm 0.004$ \\
\hline 125 & $5.98 \pm 0.09$ & $0.057 \pm 0.001$ & $8.39 \pm 0.09$ & $0.081 \pm 0.001$ \\
\hline 150 & $6.12 \pm 0.22$ & $0.060 \pm 0.004$ & $3.11 \pm 0.09$ & $0.084 \pm 0.001$ \\
\hline
\end{tabular}

Table 2. PpIX accumulation in B16F0-PDTR and B16F10-PDTR clones exposed to different ALA concentration for $24 \mathrm{~h}$ 
The ALA dose that induced the highest accumulation of intracellular PpIX in the cell line B16F0-PDTR was of $150 \mu \mathrm{g} / \mathrm{mL}\left(6.12 \pm 0.22 \mu \mathrm{g} / 8 \times 10^{5}\right.$ cells). Two-way ANOVA statistical analysis showed a significant difference in PpIX content between the lines B16F10 and B16F10-PDTR ( $\mathrm{p}<0.05$ ) starting from $25 \mu \mathrm{g} / \mathrm{mL}$ of ALA (Fig. 1-A). With regard to B16F10PDTR PpIX levels obtained were higher compared with the B16F10 (Fig. 1-B) and also with those obtained in B16F0 or B16F0 PDTR. The highest level of accumulation of PpIX in B16F10-PDTR was $8.39 \pm 0.09$ with $125 \mu \mathrm{g} / \mathrm{mL}$ of ALA, this level is four times higher than that obtained with $150 \mu \mathrm{g} / \mathrm{mL}$ in B16F10.

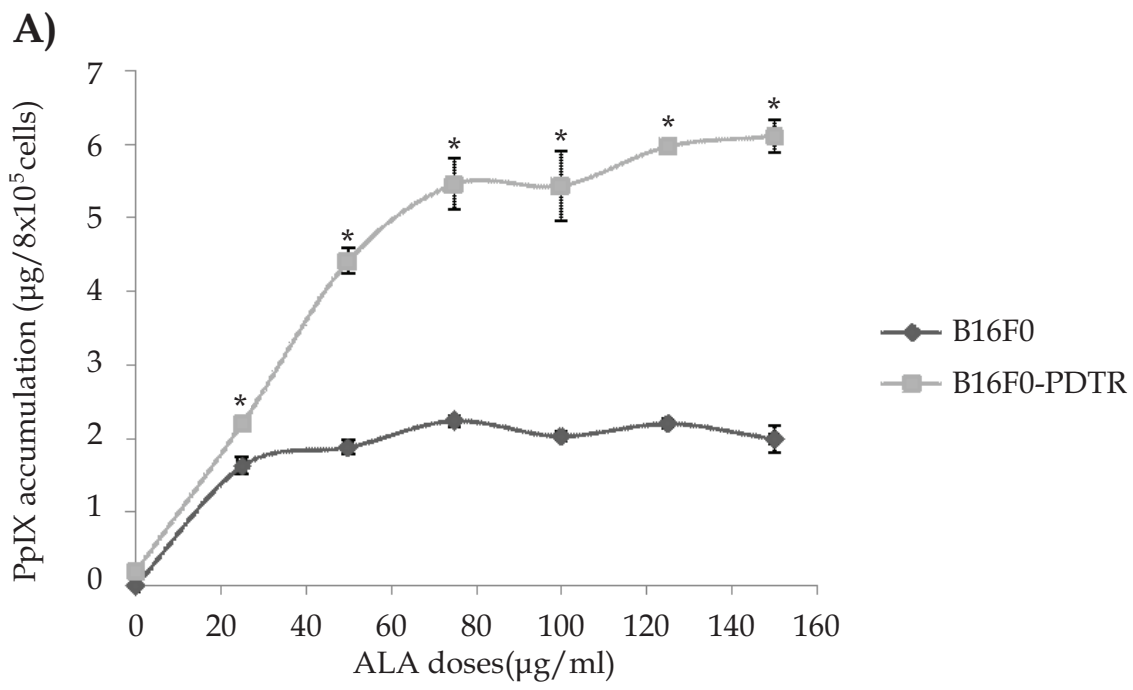

B)

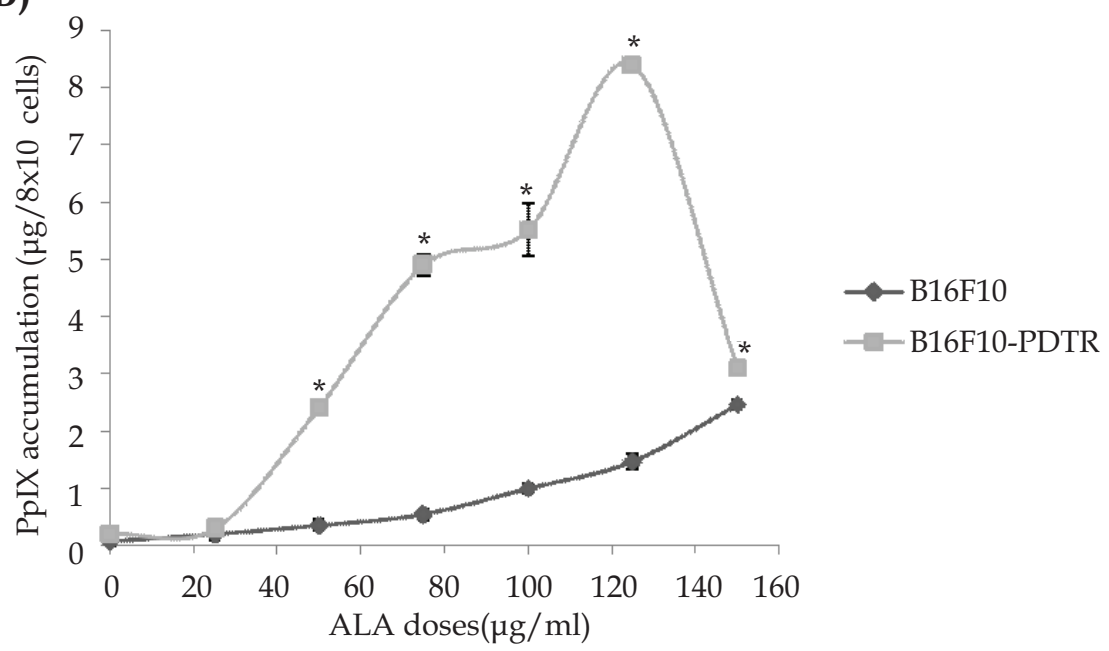

Fig. 1. Comparison of the accumulation of PpIX between B16F0 and B16F0-PDTR (A) and between B16F10 and B16F10-PDTR (B), * $p<0.05$ 


\subsection{PDT effect on cell mortality in different cell lines}

The evaluation of cytotoxicity of PDT in the four cell lines was evaluated by neutral red technique. The results are expressed as percentage of mortality at different doses of ALA (125 and $150 \mu \mathrm{g} / \mathrm{mL}$ ) exposed to a light doses of $64.3 \mathrm{~J} / \mathrm{cm}^{2}$ of irradiation. For B16F0 and B16F0-PDTR clone the mortality values ranged from 95-97\%. B16F0-PDTR had a higher sensitivity to PDT in comparison with B16F0 ( $p<0.05$ ). With regards to B16F10 and B16F10PDTR the mortality index, as well as the previous cell lines, was higher $(96 \pm 0.3 \%$ to $100 \%)$ in B16F10-PDTR. The PDT had a higher phototoxic effect when it was compared with B16F10, B16F0 and B16F0-PDTR (Fig. 2).

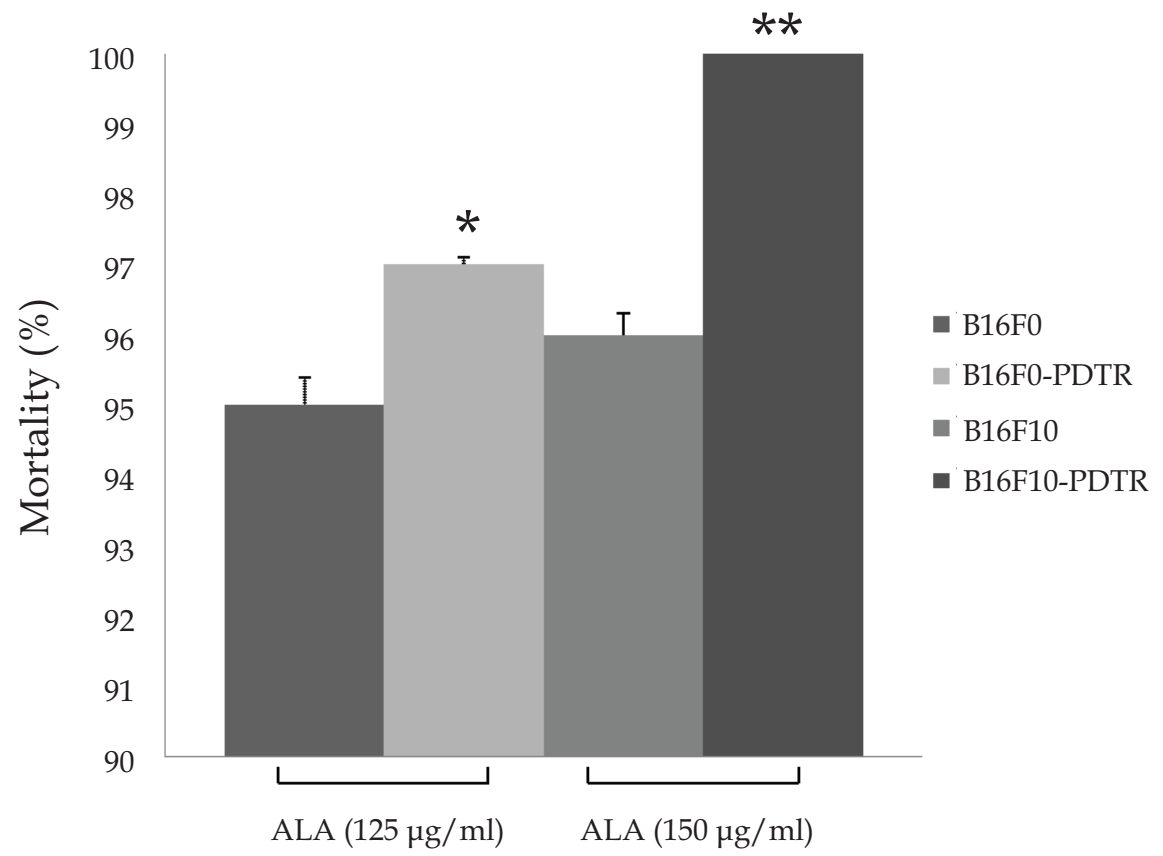

Fig. 2. Mortality percentage in the four cell lines exposed to a light doses of $64.3 \mathrm{~J} / \mathrm{cm}^{2}$. The four cell lines were treated with ALA at different doses; afterwards they were irradiated with $64.3 \mathrm{~J} / \mathrm{cm}^{2} .{ }^{*}(\mathrm{p}<0.05)$ when comparing B16F0-PDTR with B16F0 and B16F10-PDTR with B16F10

\begin{tabular}{|c|c|c|c|c|c|c|c|c|}
\hline \multirow{3}{*}{$\begin{array}{c}\text { ALA } \\
(\mu \mathrm{g} / \mathrm{mL})\end{array}$} & \multicolumn{8}{|c|}{ Mortality (\%) } \\
\hline & \multicolumn{4}{|c|}{$15 \mathrm{~J} / \mathrm{cm}^{2}$} & \multicolumn{4}{|c|}{$64.3 \mathrm{~J} / \mathrm{cm}^{2}$} \\
\hline & $\mathrm{B} 16 \mathrm{~F} 0$ & $\begin{array}{l}\text { B16F0- } \\
\text { PDTR }\end{array}$ & B16F10 & $\begin{array}{c}\text { B16F10- } \\
\text { PDTR }\end{array}$ & B16F0 & $\begin{array}{l}\text { B16F0- } \\
\text { PDTR }\end{array}$ & B16F10 & $\begin{array}{c}\text { B16F10- } \\
\text { PDTR }\end{array}$ \\
\hline 0 & 0 & 0 & 0 & 0 & 0 & 0 & 0 & 0 \\
\hline 125 & $44.39 \pm 3.6$ & $85.31 \pm 0.43$ & _ & - & $95.0 \pm 0.4$ & $97 \pm 0.1$ & - & - \\
\hline 150 & _ & _ & $91.00 \pm 0.51$ & $96.82 \pm 0.24$ & _ & _- & $96 \pm 0.3$ & 100 \\
\hline
\end{tabular}

Table 3. Percentage of mortality in the four cell lines with a light dose of 15 and $64.3 \mathrm{~J} / \mathrm{cm}^{2}$ 

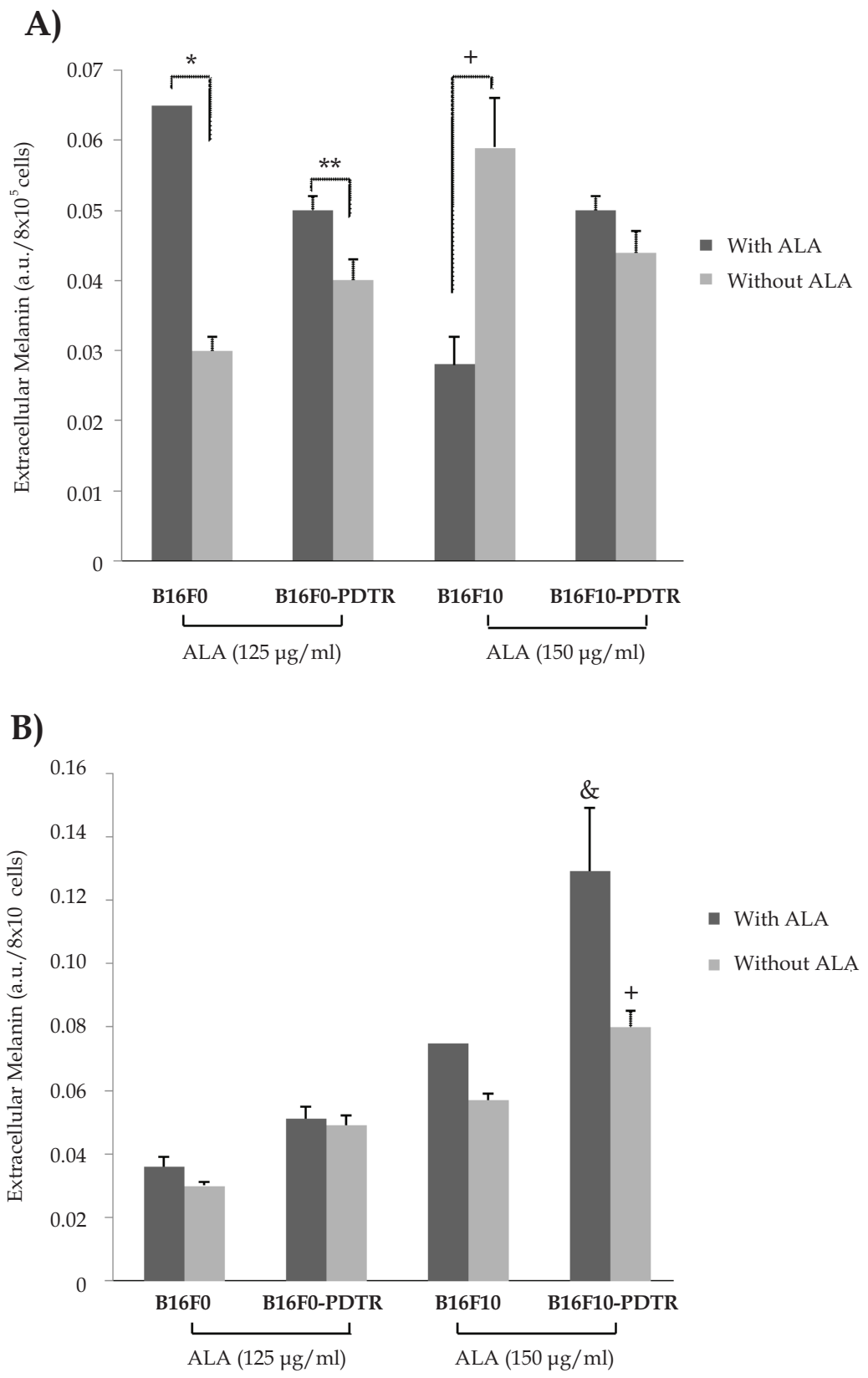

Fig. 5. Melanin concentration in four cell lines with and without ALA. A) Extracellular, B) Intracellular * $(p<0.05)$ when comparing B16F0 without ALA, ${ }^{* *}(p<0.05)$ when comparing B16F0-PDTR with B16F10-PDTR without ALA, $+(\mathrm{p}<0.05)$ with B16F10 with ALA, \& $(\mathrm{p}<0.05)$ with B16F0, B16F0-PDTR and B16F10 
The effectiveness of PDT on in vitro murine melanoma lines have been previously reported with a light dose of $15 \mathrm{~J} / \mathrm{cm}^{2}$ or minor (Vena, et al, 2004), thus in this work it was decided to find if the four lines used suffer changes in its sensitivity to PDT using a ALA dose of 125 and $150 \mu \mathrm{g} / \mathrm{mL}$ with a irradiation of $15 \mathrm{~J} / \mathrm{cm}^{2}$ (Table 3 ).

The data observed in table 3 are similar to the ones obtained with an irradiation of 64.3 $\mathrm{J} / \mathrm{cm}^{2}$. B16F10-PDTR was the most sensitive cell line with a mortality rate of $96.82 \pm 0.24$ and B16F0 had the highest survival capacity $(55.61 \%)$.

\subsection{Concentration of extra and intracellular melanin}

One of the possible mechanisms involved in the resistance to PDT is the melanin content in the cells, therefore a comparative analysis was performed between original lines and resistant clones at two levels (intracellular and extracellular). Results showed significant differences in melanin content (Fig. 5). It was observed a major concentration of intracellular melanin. The extracellular melanin content showed that B16F0 accumulates higher concentration in comparison with B16F0-PDTR (0.065 and $0.050 \pm 0.002$ a.u./8x105 cells), in addition B16F10-PDTR accumulates a higher concentration of melanin than its parental line $\left(0.050 \pm 002\right.$ and $0.028 \pm 0.004$ a.u. $/ 8 \times 10^{5}$ cells) (Fig. 5-A). Resistant cell lines accumulate a higher intracellular concentration than their parental cell line. B16F10-PDTR was the cell line that accumulates the highest intracellular melanin concentration (Fig. 5-B). The presence of ALA does not interfere with the intracellular melanin contain.

\subsection{Determination of mitochondrial activity by MTT assay}

Another variable to be analyzed was the determination of mitochondrial activity in order to study functional changes in the mitochondria caused by ALA through MTT assay. The

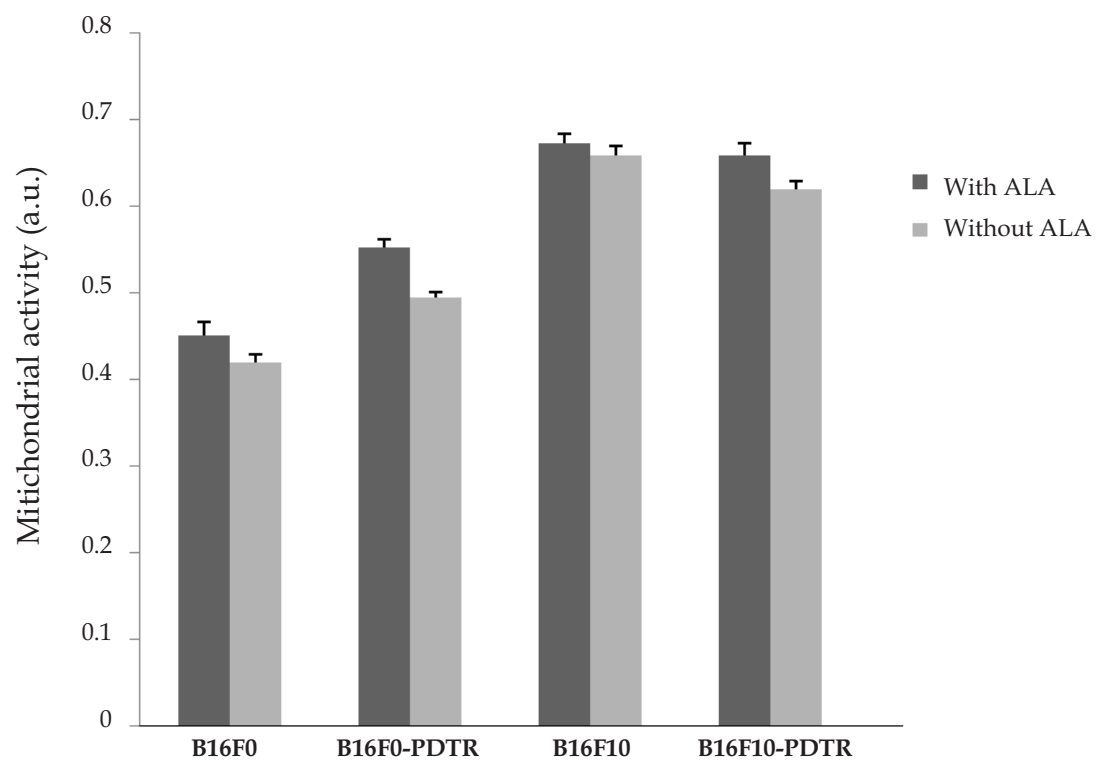

Fig. 6. Mitochondrial activity evaluated by MTT assay for B16F0, B16F0-PDTR, B16F10 and B16F10-PDTR 
mitochondrial activity was evaluated in the four cell lines. The results showed an increment in the level of mitochondrial activity in the four lines when exposed to ALA, being more evident for B16F10 and its clone in comparison with B16F0 or B16F0-RPDT (Fig. 6).

The statistical analysis of mitochondrial activity between B16F0 and B16F0-RPDT showed significant differences $(\mathrm{p}<0.05)$. B16F0-PDTR showed a higher mitochondrial activity than B16F0 with or without ALA treatment. With regard to B16F10 and B16F10-RPDT lines, statistical analysis by two-way ANOVA only showed a significant difference between them without ALA ( $\mathrm{p}<0.05)$, in addition B16F10-RPDT had a higher mitochondrial activity than B16F10, however they did not show significant differences in the treatment with ALA.

\subsection{Mitochondrial abundance determination using fluorescent probes}

As can be observed in table 4 B16F0 showed a higher mitochondrial light intensity $(47.14 \pm 1.40)$ than the other three cell lines follower by B16F10-PDTR $(45.01 \pm 1.04)$, B16F10 (34.75 \pm 0.71$)$ and finally B16F0-PDTR (31.23 \pm 0.77$)$ (Table 4).

\begin{tabular}{|c|c|c|c|c|}
\hline \multirow{2}{*}{ Fluorescent probe } & \multicolumn{4}{|c|}{ Light Intensity (\%) } \\
\cline { 2 - 5 } & \multicolumn{4}{|c|}{ Cell line } \\
\cline { 2 - 5 } & B16F0 & B16F0-PDTR & B16F10 & B16F10-PDTR \\
\hline MitotrackerGreen FM & a47.14 \pm 1.40 & a 31.23 \pm 0.77 & b34.75 \pm 0.71 & b $45.01 \pm 1.04$ \\
\hline
\end{tabular}

Table 4. Mitochondrial abundance in cell lines measured by fluorescent probes. a26 fields, b30 fields
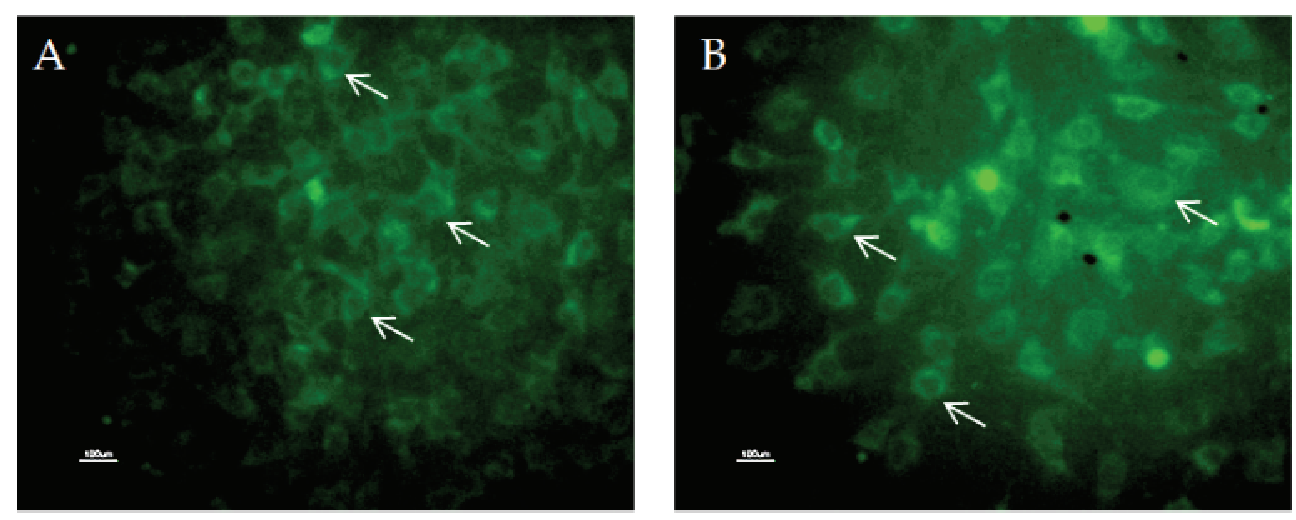

Fig. 7. Shows a representative image of the mitochondrial abundance in B16F10 (A) and B16F10-PDTR (B). The resistant cells B16F10-PDTR show a high light intensity compared with original cells, this suggests that there are a great number of mitochondria in these cells that could be involved in the process of resistance to PDT. Arrows indicate cells with fluoresce

3.7 Global analysis between the Photodynamic effect on parental melanoma cells and their resistant clones and the PpIX, melanin concentration, mitochondrial activity and mitochondrial concentration

A global analysis of the results is shown in table 5. The photodynamic effect can be observed by means of cellular death using two light doses $\left(16\right.$ and $\left.64.3 \mathrm{~J} / \mathrm{cm}^{2}\right)$ and by observing that 
the cells that survive the first irradiation (B16F0-PDTR and B16F10-PDTR) when are irradiated for the second time become more sensitive; probably this effect is not clearly seen when it is used the wave length of $64.3 \mathrm{~J} / \mathrm{cm}^{2}$, but when it is used a wave length of $16 \mathrm{~J} / \mathrm{cm}^{2}$ the mortality in the resistant cells of the line B16F0 exposed to $\mu \mathrm{g}$ ALA/mL doubles in the resistant line, it as from $44.39 \%$ of mortality to $85.31 \%$, this correlates with the concentration of extracellular melanin, it increases significantly when cells are exposed to ALA. Since it is so high the mortality in the line B16F10 this only increases $2 \%$ and the extracellular melanin has no change. The mitochondrial activity increased significantly in the resistant clona B16F0-PDTR, whereas in the other lines though there is an increase from 10 to $20 \%$ this one is not significant. In addition it can be observed that the concentration of PpIX increased in resistant cells.

\begin{tabular}{|c|c|c|c|c|c|c|c|c|c|}
\hline \multirow[t]{2}{*}{ Cell line } & \multirow{2}{*}{$\begin{array}{c}\text { ALA } \\
(\mu \mathrm{g} \\
\mathrm{ALA} / \mathrm{mL})\end{array}$} & \multirow{2}{*}{$\begin{array}{c}\text { Intracell } \\
\text { PpIX } \\
\mu \mathrm{g} / 8 \times 10^{5} \\
\text { cel }\end{array}$} & \multirow{2}{*}{$\begin{array}{l}\text { PpIX } \\
\text { ratio }\end{array}$} & \multicolumn{2}{|c|}{$\begin{array}{c}\text { Photodynamic } \\
\text { effect } \\
\text { (\% Mortality) }\end{array}$} & \multicolumn{2}{|c|}{$\begin{array}{c}\text { Melanin } \\
\text { concentration } \\
\text { (a.u./8x105 cells) }\end{array}$} & \multirow{2}{*}{$\begin{array}{l}\text { Mito- } \\
\text { chondial } \\
\text { activity }\end{array}$} & \multirow{2}{*}{$\begin{array}{c}\text { Mito- } \\
\text { chondrial } \\
\text { abundance }\end{array}$} \\
\hline & & & & $\begin{array}{c}16 \\
\mathrm{~J} / \mathrm{cm}^{2}\end{array}$ & $\begin{array}{c}64.3 \\
\mathrm{~J} / \mathrm{cm}^{2}\end{array}$ & $\begin{array}{l}\text { Intra- } \\
\text { cellular }\end{array}$ & $\begin{array}{l}\text { Extra- } \\
\text { cellular }\end{array}$ & & \\
\hline \multirow[t]{2}{*}{ B16F0 } & 0 & $0 \mathrm{~d}$ & - & 0 & 0 & 0.03 & $0.03^{a}$ & 0.43 & 47 \\
\hline & 125 & $2.21^{\mathrm{d}}$ & 1.2 & 44.39 & 95 & 0.039 & $0.07^{a}$ & 0.45 & - \\
\hline \multirow{2}{*}{$\begin{array}{l}\text { B16F0- } \\
\text { PDTR }\end{array}$} & 0 & $0.20 \mathrm{e}$ & - & 0 & 0 & 0.048 & $0.04^{b}$ & $0.48^{c}$ & 31.23 \\
\hline & 125 & $5.98^{\mathrm{e}}$ & 30 & 85.31 & 97 & 0.05 & $0.06^{\mathrm{b}}$ & $0.65^{c}$ & - \\
\hline \multirow[t]{2}{*}{ B16F10 } & 0 & $0.06^{\mathrm{f}}$ & - & 0 & 0 & 0.06 & 0.06 & 0.65 & 34.75 \\
\hline & 150 & $2.45^{f}$ & 40 & 95 & 96 & 0.65 & 0.03 & 0.68 & - \\
\hline \multirow{2}{*}{$\begin{array}{c}\text { B16F10- } \\
\text { PDTR }\end{array}$} & 0 & $0.19 \mathrm{~g}$ & - & 0 & 0 & 0.08 & 0.045 & 0.63 & 45 \\
\hline & 150 & $3.11 \mathrm{~g}$ & 16 & 97 & 100 & 0.12 & 0.05 & 0.65 & - \\
\hline
\end{tabular}

PpIX ratio=[PpIX at 125 or $150 \mu \mathrm{g}$ ALA/mL]/[PpIX at $0 \mu \mathrm{g}$ ALA/mL]. a,b,c,d,ef,g $\mathrm{p}<0.01$

Table 5. Global analysis between the Photodynamic effect on parental melanoma cells and their resistant clones

\section{Discussion}

Malignant melanoma is one of the most aggressive cancer, in addition is resistant to the ordinary therapies (chemotherapy, immunotherapy and radiotherapy) (Gray et al., 2007), thus is necessary to look for new treatments; photodynamic therapy is a hopeful therapy that presents some advantajes over surgery and radiotherapy, however clinical results have been variable. The aim of this work was to evaluate the possibles mechanism involved in resistance to PDT of two differents resistant melanoma cell lines (B16F0-PDTR, B16F10PDTR) derived from a invasive weakly and strong metastatic melanoma cell lines (B16F0 and B16F10).

In this work were obtained clonas of murine melanoma resistant to PDT as well as previous studies have obtained resistant clonas of colon adenocarcinome HT29-P14 to PDT (Hanlon et al., 2001) and mouse fibrosarcome Rif-8A (Di Prospero et al., 1997).

One of the mechanisms evaluated in this project was the concentration of intracellular PpIX because the amount of photosentizer induces the generation of reactive oxygen species (ROS) that leads to the increment cellular death. The results obtained showed that the PpIX is concentrated intracellularly and not extracellularly, also it was observed an accumulation of PpIX highly significant $(\mathrm{p}<0.05)$ in B16F0-PDTR compared with B16F0 in all ALA doses 
evaluated. A similar behavior was observed in B16F10-PDTR from $50 \mu \mathrm{g} / \mathrm{mL}$. The higher concentration of PpIX of isolated cells with regard to parental lines could be due to different factors such as the difference in the expression of enzymes involved in the hemo biosynthesis (Ruiz et al., 2007), which showed differences between retinoblastoma cell lines Y-79 and WERI-Rb-1, mediated RT-PCR found that protoporphyrinogen oxidase, uroporphyrinogen synthase, and 5-aminolevulinate synthase were over expressed, these enzymes favored the synthesis of PpIX. On the other hand, it has been reported that ferrochelatase enzyme is decreased in its activity in cancer cells; therefore this contributes to the intracellular accumulation of PpIX (Li et al., 2001). Another factor that allows the biosynthesis of PpIX is the assimilation of ALA like as it was observed in murine fibrosarcoma cells MethA (Ohgari et al., 2005). Acording with the results obtainned in this work the chossen concentration of ALA was $125 \mu \mathrm{g} / \mathrm{mL}$ to B16F0 and $150 \mu \mathrm{g} / \mathrm{mL}$ to B16F10. Another important factor that is involved in PDT is the light intensity, previous studies evaluated PDT with murine melanoma using $15 \mathrm{~J} / \mathrm{cm}^{2}$ or low doses (Inuma et al., 1994; Vena et al.2004), in this work it was compared the efficency of PDT using $15 \mathrm{~J} / \mathrm{cm}^{2}$ and 64.3 $\mathrm{J} / \mathrm{cm}^{2}$, our results showed that the use of a higher light dose increases cells mortality in the 4 cell lines tested, but the higher mortality was observed in isolated clones.

In this study was eliminated between $95-100 \%$ of melanoma cells and its clones, the most susceptible cells were the B16F10-PDTR, highly metastatic melanoma cells resisted the first application of the PDT, but were totally sensitively to the second irradiation.

Other parameter analyzed in the resistant to PDT was the melanin content. The results showed a higher intracellular accumulation of melanin. In relation with this its has been reported that PpIX can induced melanogenesis since PpIX is one activator of melanin synthesis through guanilate ciclase activation (Soo-Kyeong et al., 2005). Previous studies showed that pigmented melanoma does not has a good efficiency using PDT because the melanin interfere with the light absorption, as melanin absorbs and disperse light and decrees the production of ROS (Dea-Seon et al., 2004). Nevertheless the melanin that seems to be involved in the resistance in the melanoma cells studied in this work is extracellular, nevertheless the melanin that seems to be involved in the resistance of the melanoma cells studied in this work is the extracellular, probably this effect is not clear when it was used the density of energy of $64.3 \mathrm{~J} / \mathrm{cm}^{2}$, but when it was used a density of $16 \mathrm{~J} / \mathrm{cm}^{2}$ the cellular death in the resistant cells of the line B16F0 exposed to $125 \mu \mathrm{g}$ ALA/mL doubles in the resistant line, goes from 44.39 to $85.31 \%$ of mortality.

With regard to the analysis of the concentration and mitochondrial activity, only the latter appears to be involved, for example in the table 5 it can be observed that this activity only increases significantly in the resistant clone B16F0-PDTR, while in other lines though there is an increase from 10 to $20 \%$ it is not significant ( $p>0.05$ ). Consequently, it could be carefully inferred that the increase in mitochondrial activity makes the cells susceptible to PDT only if there are significant amounts of PpIX and extracellular melanin.

\section{Conclusion}

The resistant clones (B16F0-PDTR, B16F10-PDTR) accumulate more PpIX than the parental lines (B16F0 and B16F10).

The factors involved in the resistance of melanoma cells are extracellular melanin (the higher the concentration of melanin the bigger the resistant to PDT), mitochondrial activity (the decrease of mitochondrial activity promotes resistance) and the concentration of PpIX 
(the smaller PpIX there is less cell death). It seems that the irradiation stimulates changes in cellular metabolism related with the mitochondria that diminishes the resistance of melanoma cells, thus it would be recommendable irradiate the cells several times and at densities of $64.3 \mathrm{~J} / \mathrm{cm}^{2}$ or more. With the implementation of a laser of argon and irradiating to $64.3 \mathrm{~J} / \mathrm{cm}^{2}$ it was achieved a mortality between $95-100 \%$ of PDTR B16F0, B16F10-PDTR, B16F0 and B16F10 cells.

\section{Acknowledgment}

The Authors are grateful to Anayansi Molina and F. Arena-Huertero, PhD, Departamento de Neurociencias, Instituto de Fisiología Celular-Universidad Nacional Autónoma de México for kindly providing us with the fluorescence microscopy. ER-G received EDI, COFAA, and SNI fellowships. Financing for this study was provided by the Secretaria de Investigación y Posgrado (SIP) of Instituto Politécnico Nacional through project 20090324 and CONACyT through project 57326.

\section{References}

ACS, 2011. American Cancer Institute. Date of access: March 24, 2011, Available from: <http://www.cancer.org/Cancer/SkinCancer-

Melanoma/DetailedGuide/melanoma-skin-cancer-key-statistics>

Bonnett, R. (2000). Chemical Aspects of Photodynamic Therapy. Singapore: Gordon and Breach Science Publishers.

Borenfreud, E. S. (1985). Toxicity monitored with a correlated set of cell-cultured assays. Xenobiotica, 85, 705.

Bugaj, A., Morliére, P., Haigle, J., \& Stanislaw, D. (2004). Photototicity of Protoporphyrin IX, Diarginine Diprotoporphyrinate and N,N-Dyphenylalanyl Protopprphytin Toward Human Fibroblast and Keratinocytes In Vitro: Effect of 5-Methoxypsoralen. Photochemestry and Photobiology, 80_468-491.

Dea-Seon, L., Hwan, S., \& Won-Yo, L. (2004). Silkworm-pheophorbide a mediated photodinamic against B16F0 pigmented melanoma. Journal of photochemistry and photobiology B: Biology, 74: 1-6.

Di Prospero, L., Singh, G., Wilson, B., \& Rainbow, A. (1997). Cross-resistance to photofrinmediated photodynamic therapy and UV light and recovery form photodynamic therapy damage in Rif-8A mouse fibrosarcoma cells measured using viral capacity. Journal of Photochemestry and Photobiology, 38:143-151.

Gray, S., Willbrock, C., \& R, M. (2007). Melanoma biology and new target theraphy. 44: 851857.

Hanlon, J., Adams, K., Rainbow, A., Gupta, R., \& Singh, G. (2001). Induction of Hsp60 by photofrin-mediated photodynamic therapy. Journal of Photochemestry and photobiology, 56:55-61.

Inuma, S., Farshi, S., B, O., \& Hasan, D. (1994). A mechanistic study of cellular photodestruction with 5-aminolevulinic acid- induced porphyrin. British Journal of cancer, 70: 21-28.

Juzenas, P., Juzeien, A., Stakland, S., Iani, V., \& Moan, J. (2002). Photosensitizing effecf of protoporphyrin IX in pigmented melanoma mice. Biochemical and Biophysical Research Comunications, 297:468-472. 
Kim, M., Koh, Y. J., Kim, K. E., Koh, B. I., Nam, D.-H., Alitalo, K., Kim, I., Koh, G. Y. CXCR4 Signaling Regulates Metastasis of Chemoresistant Melanoma Cells by a Lymphatic Metastatic. Cancer Res; 70(24); 10411-21.2010.

Li, W., Shang, W., Ohnishi, K., Yamada, I., Ohno, R., \& Hashimoto, K. (2001). 5-aminolevulinic acid- mediated photodynamic therapy in multidrug resistant leukemia cells. Journal of photochemistry and photobiology B:Biology, 60: 79-86.

Mang, T. (2004). Lasers and Light sources for PDT: past, present and future. Photodiagnosis and Photodynamic Therapy, 1:43-48.

Martínez SH. El primer Consenso Nacional de Expertos en Melanoma. Gac Mex Oncol 2005;4(2):11-13.

Mossman, T. (1983). Rapid colorimetric assay for cellular growth and survival application to proliferation and citotoxicity assays. Journal of Immunological Methods, 65, 55.

Mossman, T. (1983). Rapid colorimetric assay for cellular growth and survival application to proliferation and citotoxicity assays. Journal of Immunological Methods, 65, 55.

Ohgari, Y., Nakayasu, Y., Kitajima, S., Sawamoto, M., Mori, H., Shimokawa, O. M., y otros. (2005). Mechanisms involved in 5-aminolevulinic acid (ALA)- induced photosensitivity of tumor cells: Relation of ferrochelatase and uptake of ALA to the accumulation of protoporphyrin. Biochemical Pharmacology, 71:42-49.

Paras, P. (2003). Introduction to Biophotonics. New Jersey, USA. John Wyley and Sons; 433445.

Piomelli, S. A. (1973). Micromethod for free erythrocyte porphyrins: The FEP test. J. Lab. Clin. Med., 932-940.

Rad, H. H., Yamashita, T., Y., J. H., Hirosaki, K., Wakamatsu, K., Ito, S. (2004). Tyrosinaserelated proteins suppress tyrosinase-mediated cell death of melanocytes and melanoma cells. Exp Cell Res, 298, 317.

Ramón, G. E., DeLeón, R. I., Martínez, G. L., \& Pérez, Z. A. (1999). In vitro study of biosynthesis of protoporphyrin IX induced by d-aminolevulinic acid in normal and cancerous cells of the human cervix. 30, 163-170.

Ruiz, G., Arenas, H., \& Ramon, G. (2007). Expression of genes involved in hemo biosynthesis in the human retinoblastoma cell lines WERI-Rb-1 and Y-79: implications for photodynamic therapy. J. Exp. Clin. Cancer Research, 195-200

Sheleg, S., Zhavrid, E., Khodina, T., Kochubeev, G., Istomin, Y., Chalov, V., y otros. (2004). Photodynamic therapy with chorine e6 for skin metastases of melanoma. Photodermatology Photoinmunology and Photomedicine, 20:21-26.

Van-Hillegerberg VR, Kort WJ., Wilson JH., Current status of photodynamic therapy in oncology. Drug 1994;48:510.

Vena, F., Turchiello, R., Laville, I., Pigaglio, S., Blais, J., \& Tudesco, A. (Lasers in medical Science). 5-aminolevulinic acid ester- induced protoporphyrin IX in a murine melanoma cell line. 2004, 19: 119-126.

WHO, 2011. World Health Organization. Date of access: March 24, 2011, Available from: <http://www.who.int/uv/faq/skincancer /en/index1.html>

Zhu, T., \& Finlay, J. (2008). The role of photodynamic therapy (PDT) physics. Am. Assoc. Phys. Med, 3127-3136. 


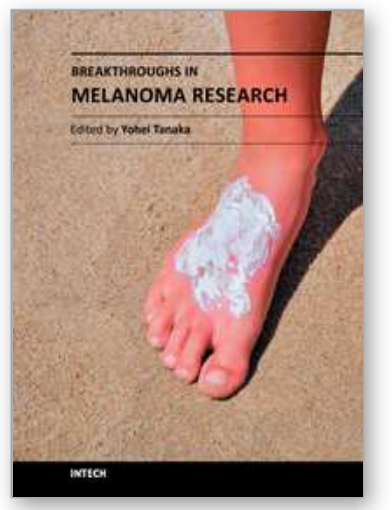

\author{
Breakthroughs in Melanoma Research \\ Edited by Dr Yohei Tanaka
}

ISBN 978-953-307-291-3

Hard cover, 628 pages

Publisher InTech

Published online 30, June, 2011

Published in print edition June, 2011

Melanoma is considered to be one of the most aggressive forms of skin neoplasms. Despite aggressive researches towards finding treatments, no effective therapy exists to inhibit the metastatic spread of malignant melanoma. The 5-year survival rate of metastatic melanoma is still significantly low, and there has been an earnest need to develop more effective therapies with greater anti-melanoma activity. Through the accomplishment of over 100 distinguished and respected researchers from 19 different countries, this book covers a wide range of aspects from various standpoints and issues related to melanoma. These include the biology of melanoma, pigmentations, pathways, receptors and diagnosis, and the latest treatments and therapies to make potential new therapies. Not only will this be beneficial for readers, but it will also contribute to scientists making further breakthroughs in melanoma research.

\title{
How to reference
}

In order to correctly reference this scholarly work, feel free to copy and paste the following:

Ramón-Gallegos E., Rosas-Flores L., Barrera-Mendoza C.C., Herrera-Carrillo Z., González-Agüero G., Estrada-Manrique G. and Cruz-Orea A. (2011). Isolation of Cellular Clones of Murine Melanoma Resistants to the Photodynamic Therapy and Characterization of Some Mechanisms Involved in the Radioresistance, Breakthroughs in Melanoma Research, Dr Yohei Tanaka (Ed.), ISBN: 978-953-307-291-3, InTech, Available from: http://www.intechopen.com/books/breakthroughs-in-melanoma-research/isolation-of-cellular-clones-ofmurine-melanoma-resistants-to-the-photodynamic-therapy-and-character

\section{INTECH}

open science | open minds

\section{InTech Europe}

University Campus STeP Ri

Slavka Krautzeka 83/A

51000 Rijeka, Croatia

Phone: +385 (51) 770447

Fax: +385 (51) 686166

www.intechopen.com

\section{InTech China}

Unit 405, Office Block, Hotel Equatorial Shanghai

No.65, Yan An Road (West), Shanghai, 200040, China

中国上海市延安西路65号上海国际贵都大饭店办公楼 405 单元

Phone: +86-21-62489820

Fax: $+86-21-62489821$ 
(C) 2011 The Author(s). Licensee IntechOpen. This is an open access article distributed under the terms of the Creative Commons Attribution 3.0 License, which permits unrestricted use, distribution, and reproduction in any medium, provided the original work is properly cited. 